AGNIESZKA NITSZKE

Uniwersytet Jagielloński, Kraków

DOI : $10.14746 /$ rie.2016.10.24

\title{
W kierunku nowej Europejskiej Polityki Sąsiedztwa Unii Europejskiej
}

\begin{abstract}
Wstęp
Europejska Polityka Sąsiedztwa (EPS) powstała w bardzo szczególnym momencie rozwoju integracji europejskiej. W 2004 r. doszło do największego w historii rozszerzenia - do Unii Europejskiej przystąpiło 10 państw Europy Środkowo-Wschodniej, a dwa kolejne państwa regionu przystapiły w 2007 r. Doprowadziło to do zmiany granic zewnętrznych Unii Europejskiej, a co za tym idzie państw sąsiadujących z UE. Zmienił się w ten sposób także kontekst geopolityczny Unii. EPS jest obszarem współpracy, w ramach którego UE balansuje między idealizmem a realizmem. Z jednej strony EPS to szczytne zasady i cele - promocja praw człowieka, demokracji, wsparcie w walce z ubóstwem, rozwój społeczeństwa obywatelskiego, rozwój sektora małych i średnich przedsiębiorstw (MŚP), etc. Z drugiej strony to obawa o charakter reżimów politycznych i skutki ich polityki wewnętrznej, która może prowadzić do obniżenia poziomu bezpieczeństwa w samej Unii Europejskiej. EPS, nie bez powodu, jest określana jako ,polityka buforowa”. Pod tym pojęciem kryje się zasadniczy cel tej polityki, czyli budowanie strefy pokoju i szeroko rozumianego bezpieczeństwa, w tym także pozamilitarnego - socjalnego czy ekologicznego, w państwach, które mają granice lądowe lub morskie z Unią Europejską.

Po przeszło 12 latach realizacji EPS i dwóch wstrząsach politycznych - kryzysie ukraińskim i arabskiej wiośnie, nadszedł czas kompleksowej oceny i rewizji niektórych założeń. W 2015 r. rozpoczęły się konsultacje dotyczące nowego kształtu EPS, tak by polityka ta $\mathrm{z}$ jednej strony nadal wypełniała swoją zasadniczą funkcję wspierania i promocji praw człowieka i demokracji w państwach sąsiedzkich, ale z drugiej strony by UE mogła efektywniej wpływać na swoje bezpieczeństwo zewnętrzne. Po ponad półrocznym okresie konsultacji, w których udział wzięły zarówno instytucje UE, państwa członkowskie, a także organizacje pozarządowe, w listopadzie 2015 roku Komisja Europejska przedstawiła założenia reformy EPS, którą można określić jako nową Europejską Politykę Sąsiedztwa.

W literaturze przedmiotu dotychczas pojawił się szereg publikacji dotyczących zarówno genezy, jak i ewolucji EPS, wśród których warto zwrócić uwagę na: $E u$ ropejska polityka sqsiedztwa Unii Europejskiej: geneza, doświadczenia, perspektywy (red. Fiszer, 2012), Europejska Polityka Sasiedztwa. Unia Europejska i jej sqsiedzi - wzajemne relacje i wyzwania (Marcinkowska, 2011), Polityka Sasiedztwa Unii Europejskiej. Pomostowość czy buforowość? (red. Jartyś, Staszczyk, 2008) oraz pozycje obcojęzyczne: European Neighbourhood Policy and the Democratic Values of the EU (Ghazaryan, 2014), European Neighbourhood Policy: Challenges for the EU-Policy
\end{abstract}


Towards the New Neighbours (red. Varwick, Lang, 2007), The Influence of EU Member States on European Neighbourhood Policy. A Comparative Analysis of Germany, France and Poland (Normann, 2014), Die Entstehung und Entwicklung der Europäischen Nachbarschaftspolitik. Akteure und Koalitionen, Europäische Schriften (Böttger, 2010). Nowa Europejska Polityka Sąsiedztwa, z uwagi na aktualność zagadnienia, nie doczekała się jeszcze kompleksowego opracowania. Niniejszy artykuł stanowi próbę uzupełnienia badań w tym zakresie.

Zmiany polityczne i geopolityczne, które zachodzą w świecie od 2011 r., czyli wydarzenia arabskiej wiosny i ich konsekwencje, a także dotychczas nierozwiązany kryzys ukraiński, powodują nowe wyzwania dla Unii Europejskiej. Wszystko to ma miejsce w czasie, gdy sama UE boryka się z poważnymi problemami wewnętrznymi, w tym z kryzysem gospodarczym i kryzysem strefy euro oraz największym wyzwaniem politycznym w historii integracji, czyli Brexitem. Odpowiedzią Unii na wyzwania zewnętrzne jest reforma podejścia do państw sąsiedzkich i próba stworzenia nowego modelu współpracy z bardziej aktywną i efektywną rolą Europy w kształtowaniu relacji z partnerami. W artykule przedstawiony zostanie dotychczasowy model EPS, w tym także przesłanki ustanowienia polityki w 2004 r., następnie ukazana zostanie ewolucja EPS, a w kolejnej części artykułu omówione zostaną założenia nowej EPS na podstawie analizy dokumentów instytucji UE. Celem artykułu jest próba odpowiedzi na następujące pytania badawcze: P1. Czy realizacja pierwotnych założenia EPS zakończyła się fiaskiem?; P2. Czy UE ma realne możliwości oddziaływania na państwa sąsiedzkie?; P3. Czy nowa EPS ma szanse na sprostanie aktualnym wyzwaniom geopolitycznym?; P4. Czy EPS stanowi filar bezpieczeństwa zewnętrznego UE?

\section{Geneza i podstawowe cele Europejskiej Polityki Sąsiedztwa}

Pod koniec lat 90. XX w., kiedy kolejne rozszerzenie Unii o państwa Europy Środkowo-Wschodniej było już przesądzone, rozpoczęto prace nad ustanowieniem nowych instrumentów, które uwzględniałyby fakt przesunięcia granic zjednoczonej Europy oraz dawały gwarancję, że nowi sąsiedzi nie będą dla Unii problemem. Politycznym impulsem do ustanowienia EPS był list Javiera Solany, ówczesnego Wysokiego Przedstawiciela do spraw WPZiB oraz Chrisa Pattena pełniącego funkcję komisarza do spraw stosunków zewnętrznych, przedstawiony 7 sierpnia 2002 r. (Patten, Solana, 202, passim). Propozycjami sformułowanymi w tym dokumencie w pierwszej kolejności zajęła się Rada UE, uznając konieczność sformalizowania relacji z nowymi sąsiadami, a następnie Rada Europejska, która na szczycie w Kopenhadze w grudniu 2002 r. zaznaczyła, że rozszerzenie nie może powodować powstania nowych linii podziału w Europie oraz że rolą UE jest promowanie dobrobytu i stabilności, także poza swoimi granicami (Coun$c i l, 2002)$. Na tej podstawie Komisja Europejska została zobligowana do przygotowania i przedstawienia dokumentu, który precyzowałby zasięg geograficzny nowej polityki oraz instrumenty jej prowadzenia. W marcu $2003 \mathrm{r}$. KE przyjęła komunikat w tej sprawie zatytułowany „Szersza Europa - Sąsiedztwo: Nowe ramy stosunków z naszymi wschodnimi i południowymi sąsiadami”. Potwierdzono w nim podział na państwa, które mają szansę na przystąpienie do UE, przede wszystkim Turcja i państwa bałkańskie, oraz 
pozostałe, czyli kraje wschodnie i położone w regionie śródziemnomorskim, które miałyby być związane z Unią bliższymi relacjami. KE zaproponowała, by połączyć ze sobą dwa obszary współpracy: gospodarczej i politycznej. W ramach tej pierwszej UE zaoferowała liberalizację dostępu do swojego rynku dla produktów pochodzących z państw objętych EPS, a także - ułatwienia w przepływie usług, kapitału i osób. W zakresie współpracy politycznej położono nacisk na demokratyzację tych państw, co miałoby się przyczynić do wyeliminowania konfliktów w bezpośrednim sąsiedztwie Unii (Szersza, 2003, passim). W czerwcu tego samego roku Rada uznała komunikat KE za dobry wstęp do dalszych prac oraz określiła cele i zasady, a także możliwe środki zachęcające. Rada Europejska na szczycie w Salonikach w czerwcu 2003 r. przyjęła wnioski Rady i zdecydowała, że Rada i Komisja powinny podjąć dalsze działania mające na celu wypracowanie spójnego programu tej polityki.

W efekcie KE przyjęła 12 maja 2004 r., czyli zaledwie kilka dni po największym w historii rozszerzeniu, kolejny komunikat poświęcony EPS pod tytułem „Europejska Polityka Sąsiedztwa - Strategia”. Stanowi on podstawę prowadzenia nowej polityki UE. Został w nim określony zakres oraz podstawowe cele i mechanizmy nowej polityki. Europejska Polityka Sąsiedztwa co do zasady skierowana jest do państw, które mają lądową bądź morską granicę z UE. Należy jednak w tym miejscu zaznaczyć, że nie oznacza to bynajmniej, że chodzi o wszystkie państwa bez wyjątku. Po pierwsze, nie są tu ujęte państwa europejskie, z którymi UE współpracuje w ramach Europejskiego Obszaru Gospodarczego, czyli Norwegia, Islandia i Liechtenstein, a także Szwajcaria. Po drugie, z EPS wyłączone są państwa, które już rozpoczęły negocjacje akcesyjne lub są w agendzie rozszerzenia (Europejska, 2004, passim). Po trzecie - Rosja, która ze względu na swoje mocarstwowe aspiracje nie mogła pozwolić sobie, aby w relacjach z UE stać na pozycji interesanta i dodatkowo być rozliczana z postępów w zakresie przemian politycznych i gospodarczych (Zięba, 2007, s. 159-167). Zwrócono uwagę na różnice między problemami i wynikającymi z nich wyzwaniami w stosunkach z partnerami wschodnimi oraz południowymi. Instytucjonalizacja EPS nie przebiegała w próżni, lecz była kontynuacją wcześniejszej współpracy, szczególnie w relacjach z południowymi państwami śródziemnomorskimi, z którymi od 1995 r. jest rozwijany proces barceloński (Borkowski, 2005, passim).

Choć UE podkreśla, że ,nie zamierza narzucać swoim partnerom priorytetów ani warunków" (Europejska, 2004, s. 50), to oczywistym pozostaje, że jest we wzajemnych relacjach podmiotem silniejszym i że to od jej woli zależy kształt i charakter stosunków. Podstawowym instrumentem EPS w relacjach z państwami partnerskimi są plany działania. Powstają one na bazie wcześniej opracowanych raportów krajowych, w których KE ocenia zdolności instytucjonalne poszczególnych państw, stan ich gospodarki, biorąc pod uwagę podstawowe wskaźniki makroekonomiczne, a także sytuację polityczną w ujęciu zarówno wewnętrznym, jak i międzynarodowym. Jeśli ocena zawarta w raporcie jest pozytywna, wówczas rozpoczyna się proces negocjacyjny prowadzący do sformułowania planu działania, który ma charakter umowy dwustronnej między UE a konkretnym państwem. Takie rozwiązanie miało zapewnić elastyczność doboru środków do problemów, z którymi borykają się poszczególne państwa. Jednak by zagwarantować spójność całej polityki, tak aby nie stała się jedynie zbiorem dwustronnych umów, sporządzono katalog wspólnych wartości, które mają być każ- 
dorazowo przestrzegane i realizowane. Wśród nich znalazły się kwestie o fundamentalnym znaczeniu dla bezpieczeństwa UE, czyli zobowiązanie państw partnerskich do transformacji ustrojowej w kierunku demokratyzacji, przestrzegania praw człowieka, w tym mniejszości, rozwijania praworządności, czy zwalczania przestępczości zorganizowanej i różnych form radykalizmu i ekstremizmu, w tym terroryzmu ${ }^{1}$. Wiązało się to bezpośrednio z zaangażowaniem $\mathrm{w}$ dialog polityczny, który miał obejmować kwestie polityki zagranicznej i bezpieczeństwa, w tym takie elementy jak rozstrzyganie konfliktów i zarządzanie kryzysowe oraz zapobieganie rozprzestrzenianiu broni masowej zagłady. W ten sposób $\mathrm{w}$ ramach planów działania miały być realizowane cele, na których zależy szczególnie Unii i które, zwłaszcza w perspektywie krótkookresowej, mogą wydawać się państwom sąsiedzkim trudne do zrealizowania, a niekiedy nawet nie do przyjęcia. Należało zatem wprowadzić element zachęty dla podjęcia trudu przemian politycznych. Państwa partnerskie najbardziej były, i nadal są, zainteresowane dostępem do rynku unijnego. UE oferuje państwom sąsiedzkim szereg koncesji i ułatwień we wzajemnej wymianie handlowej, przy czym towary importowane muszą spełniać wysokie standardy i normy jakościowe obowiązujące w Unii. A to oznacza konieczność przyjmowania przez te państwa podobnych do unijnych regulacji prawnych ${ }^{2}$. Stanowi to kolejny element „europeizacji” państw partnerskich, czyli poszerzania przez Unię swoich wpływów, w tym wypadku normatywnych ${ }^{3}$. Na efekty tych rozwiązań trzeba poczekać przynajmniej kilka lat, tymczasem należy zaoferować państwom sąsiedzkim wsparcie, którego pozytywne skutki będą odczuwalne dla ich gospodarek, a przez to społeczeństw, niemal natychmiastowo. Temu służą środki wsparcia finansowego. Już od wczesnych lat 90 . XX w. Wspólnoty angażowały się w pomoc materialną dla państw Europy Wschodniej. Uruchomiono wówczas Program Pomocy Technicznej dla Wspólnoty Niepodległych Państw (Technical Assistance for the Commonwealth of Independent States - TACIS). Także w ramach współpracy z państwami południowymi istniał specjalny program MEDA (fr. Mesures d'Accompagnament, pol. środki wspierające). Oprócz tego działał Europejski Instrument na rzecz Demokracji i Praw Człowieka (European Instrument for Democracy and Human Right - EIDHR), który miał charakter horyzontalny ${ }^{4}$ KE w obu powyżej

${ }^{1}$ W komunikacie Europejska Polityka Sasiedztwa - Strategia, w rozdziale poświęconym Planom Działania znalazł się obszerny punkt mówiący o zaangażowaniu we wspólne wartości, przy czym są to wartości europejskie, niekoniecznie chętnie i powszechnie podzielane przez państwa, do których EPS jest skierowana. W dokumencie znajduje się również odwołanie do międzynarodowych systemów ochrony praw człowieka, przede wszystkim do konwencji ONZ o prawach człowieka czy Europejskiej konwencji o ochronie praw człowieka i podstawowych wolności. Unia zamierza popierać i promować te wartości w państwach trzecich (Europejska, 2004, s. 55).

${ }^{2} \mathrm{KE}$ zaznacza, że takie rozwiązanie przyniesie krajom sąsiedzkim korzyści nie tylko związane ze wzrostem wymiany handlowej z UE, ale także przyczyni się do zwiększenia konkurencyjności tych państw w zakresie przyciagania nowych inwestycji zagranicznych, co spowoduje wzrost zatrudnienia, wzrost PKB i ogólnie dobrobytu. Dodatkowo, państwa te z czasem uzyskają dostęp także do innych rynków, gdyż ich produkty będą cechować się wysoką jakością i niewygórowaną ceną (Europejska, 2004, s. 57).

3 Określenie UE jako „normatywnego hegemona” w kontekście EPS pojawia się w artykule H. Haukkala (2008).

${ }^{4}$ Program EIDHR istniej nadal, przy czym został nieco zmodyfikowany. Nie jest już „Instrumentem” tylko stał się „Inicjatywą”. 
przywoływanych komunikatach zapowiadała stworzenie Europejskiego Instrumentu Partnerstwa, który miał zastąpić programy regionalne TACIS i MEDA. Wspólny mechanizm finansowy EPS powstał dopiero w 2007 r., przy czym Parlament Europejski i Rada UE w rozporządzeniu nr 1638/2006 z 24 października 2006 r. zmieniły jego nazwę na Europejski Instrument Sąsiedztwa i Partnerstwa (European Neighbourhood and Partnership Instrument - ENPI) i poszerzyły krąg podmiotów uprawnionych do korzystania ze środków finansowych o Rosję, traktowaną jako partner strategiczny (Rozporzadzenie, 2006). Ważnym elementem współpracy i wsparcia państw sąsiedzkich jest Biuro Wymiany Informacji i Pomocy Technicznej (Technical Assistance and Information Exchange - TAIEX), które służy wymianie doświadczeń oraz polega na świadczeniu usług doradztwa przez ekspertów UE, którzy uczą aparat administracyjny państw partnerskich dobrego zarządzania.

Raporty krajowe i plany działania dla większość państw zostały przygotowane i przyjęte w bardzo krótkim czasie - do końca 2006 r. Liban i Egipt przyjęły plany działania w 2007 r. Z kolei Libia, Syria i Białoruś nie podjęły współpracy z powodów politycznych (Pracujmy, 2006, s. 11). Ciekawy przypadek stanowi Algieria, z którą negocjacje są w toku od 2004 r. i dotychczas nie zakończyły się podpisaniem porozumienia. Plany działania, w zależności od możliwości poszczególnych partnerów są przyjmowane na okres od trzech do pięciu lat. W ramach tych porozumień Komisja Europejska, odpowiedzialna po stronie UE za realizację EPS, formułuje oczekiwania w zakresie reform politycznych i gospodarczych. Od strony formalnej porozumienia o współpracy mogą mieć charakter umów o partnerstwie i współpracy lub układów stowarzyszeniowych. O znaczeniu EPS dla Unii świadczy wzrost środków finansowych przeznaczanych na tę politykę w kolejnych perspektywach finansowych. W latach 2007-2013 było to 12 mld euro, a na lata 2014-2020 przewidziano środki w wysokości 15,4 mld euro (Dokumenty, 2016, s. 2).

\section{Ewolucja Europejskiej Polityki Sąsiedztwa w latach 2006-2011}

EPS nabrała realnego kształtu - dla każdego państwa zostały sformułowane działania priorytetowe, które w kolejnych latach były realizowane i podlegały ocenie ze strony instytucji UE poprzez raporty okresowe.

W trakcie realizacji EPS pojawiały się problemy i zagadnienia, które nie zostały ujęte w komunikacie KE z 2004 r. W związku z tym Komisja w kolejnych latach wydała trzy komunikaty, w których odniosła się do kwestii wcześniej nieuregulowanych, lub takich, które wymagały doprecyzowania bądź zmiany dotychczasowego podejścia. Pierwszy z komunikatów zatytułowany „W sprawie wzmocnienia Europejskiej Polityki Sąsiedztwa" z 6 grudnia 2006 r. zawierał ocenę dotychczasowych działań. W komunikacie zaprezentowano mocne i słabe strony EPS. Do pierwszych zaliczono przede wszystkim ,integrację" rozumianą jako holistyczne podejście do partnerów, gdzie współpraca gospodarcza pozostaje w ścisłym związku z kwestiami reform politycznych, co uniemożliwia partnerom UE wybiórcze realizowanie zobowiązań. Inne mocne strony, zdaniem Komisji, to: wspólna odpowiedzialność, konkretne działania i lepsze wykorzystanie środków (W sprawie, 2006, s. 3). Dużo ważniejsze, z punk- 
tu widzenia faktycznej oceny EPS, są słabe punkty wskazane w komunikacie, gdyż świadczą o chęci korekty tej polityki przez UE. Komisja wskazała trzy słabe punkty, z których każdy miał bardzo istotne znaczenie. Po pierwsze, uznano, że integracja gospodarcza i handlowa przebiega zbyt wolno. To z kolei mogło rzutować na cała politykę, ponieważ brak zachęt ekonomicznych skutkował brakiem postępów w reformach politycznych. Drugim problemem ujętym w dokumencie były kwestie związane z migracjami i mobilnością. Komisja uznała, że brak postępów w zakresie liberalizacji reżimów wizowych, zwłaszcza dla przedsiębiorców, naukowców czy studentów, może stanowić poważną przeszkodę w prawidłowej implementacji EPS. Trzeci problem, z dzisiejszej perspektywy być może najważniejszy, to nierozwiązane konflikty regionalne, które destabilizują sytuację w państwach objętych EPS ( $W$ sprawie, 2006, s. 3-4). Znamienne jest, że dalszej części komunikatu Komisja zwróciła uwage, że „Jeżeli EPS nie będzie mogła przyczynić się do rozwiązania konfliktów w regionie, będzie to oznaczało, że nie udało się zrealizować jednego z jej najważniejszych celów. Takie konflikty mogą zagrozić bezpieczeństwu Unii, z uwagi na ryzyko nasilenia się czy masowego napływu uchodźców, przerwania dostaw energii, zerwania więzi handlowych i połączeń transportowych albo poprzez rozprzestrzenianie się terroryzmu i przestępczości zorganizowanej, w tym handlu ludźmi, narkotykami i bronią" (W sprawie, 2006, s. 10). Zasadniczo dokument z $2006 \mathrm{r}$. nie ma charakteru reformującego EPS, a jedynie oceniający i uzupełniający tę politykę po pierwszej fazie jej implementacji.

Także kolejny komunikat Komisji zatytułowany „,Silna europejska polityka sąsiedztwa" przyjęty 5 grudnia 2007 r. ${ }^{5}$ nie zmienia zasadniczo głównych założeń i kierunków EPS, a jedynie, podobnie jak poprzedni dokument, koncentruje się na doprecyzowaniu pewnych elementów. Już we wstępie podkreślono, że „[...] najwięcej uwagi należy poświęcić realizacji istniejących zobowiązań, zarówno po stronie krajów partnerskich, jak i po stronie UE. Potrzebne są wysiłki obu stron" (Silna, 2007, s. 3). Ważnym elementem zaznaczonym w komunikacie było otwarcie dla państw partnerskich możliwości uczestniczenia przez nie w unijnych agencjach i programach, co daje im szansę na większe finansowanie różnych działań, a także wymianę i zdobywanie nowych doświadczeń poprzez uczestnictwo we wspólnych projektach z państwami europejskimi (Kalicka-Mikołajczyk, 2013, s. 36-37). Manifestując otwartość, Komisja podkreśliła, że także państwa, które do tej pory nie podpisały planów działania, mogą w przyszłości liczyć na wsparcie ze strony Unii. Był to ważny polityczny sygnał skierowany do Libii, Syrii, Algierii i Białorusi, pokazujący chęć włączenia tych państw w orbitę wartości i zasad UE (Silna, 2007, s. 13). Komunikat kończy się stwierdzeniem, że w kolejnym roku (2008) KE dokona oceny postępów realizacji planów działania i że na tej podstawie podjęte będą decyzje, które, choć w perspektywie krótkoterminowej, dla niektórych państw mogą być trudne, to okażą się korzystne w perspektywie długoterminowej.

${ }^{5}$ Warto zaznaczyć, że w proces oceny EPS w 2007 r. zaangażowały się także państwa członkowskie. We wrześniu tego roku Komisja zorganizowała konferencję poświęconą EPS z udziałem ministrów i przedstawicieli organizacji pozarządowych państw UE i państw partnerskich. Natomiast wcześniej prezydencja niemiecka przygotowała sprawozdanie dotyczące EPS, a konkretnie przyjętego w 2006 r. komunikatu. Zostało ono przyjęte przez Konkluzję Rady w sprawie wzmacniania europejskiej polityki sąsiedztwa (11016/07 z dnia 19 czerwca 2007 r.). 
W połowie 2010 r. rozpoczął się zainicjowany i koordynowany przez Komisję Europejską proces przeglądu EPS. W konsultacjach uczestniczyły instytucje i państwa członkowskie UE, państwa partnerskie oraz cały szereg organizacji pozarządowych. Elementem, który miał znaczenie podczas przeglądu EPS było wejście w życie Traktatu lizbońskiego (TL) 1 grudnia 2009 r., który dokonywał reformy instytucjonalnej Unii, w tym także podziału kompetencji między instytucjami. Ważnym punktem reformy TL było ustanowienie Europejskiej Służby Działań Zewnętrznych, którą kieruje Wysoki Przedstawiciel Unii do spraw Zagranicznych i Polityki Bezpieczeństwa (Wysoki Przedstawiciel) będący jednocześnie jednym z wiceprzewodniczących KE. Nowa Służba przejęła częściowo od KE zadania związane z realizacją EPS. Jeszcze w trakcie procesu przeglądu EPS rozpoczęły się przemiany polityczno-społeczne w państwach Afryki Północnej. Arabska wiosna nie była zatem przyczyną czy powodem reformy EPS, choć oczywiście wpłynęła na jej ostateczny kształt. Także w samej UE zaczęły pojawiać się pierwsze kontrowersje i podziały w odniesieniu do EPS. Państwa Europy Południowej wyrażały zainteresowanie ściślejszą współpracą z państwami południowego wymiaru EPS, czego wyrazem była propozycja Francji ustanowienia Unii dla Śródziemnomorza ${ }^{6}$. W odpowiedzi na tę propozycję Polska, wspierana przez Szwecję i przy poparciu Niemiec, zaproponowała utworzenie Partnerstwa Wschodniego skierowanego do państw wschodniego wymiaru EPS. W ten sposób doszło na przełomie 2008 i 2009 r. do formalnego wydzielenia dwóch obszarów geograficznych EPS, co odzwierciedlało preferencje i priorytety poszczególnych państw UE. W tych okolicznościach Komisja Europejska opracowała kolejny komunikat poświęcony Europejskiej Polityce Sąsiedztwa zatytułowany „Nowa koncepcja działań w obliczu zmian zachodzących w sąsiedztwie”, gdzie we wstępie wyjaśniono: „Obalenie zakorzenionych od lat represyjnych reżimów w Egipcie i Tunezji, trwający konflikt militarny w Libii, niedawne brutalne tłumienie protestów w Syrii, nieustające represje na Białorusi oraz utrzymujące i przedłużające się konflikty w regionie, w tym także na Bliskim Wschodzie, zmuszają nas do świeżego spojrzenia na stosunki UE z jej sąsiadami. [...] UE musi sprostać historycznym wyzwaniom w naszym sąsiedztwie" (Nowa, 2011, s. 1). Komisja w komunikacie odniosła się również do pozycji EPS w polizbońskim ładzie prawnym. EPS powinna pozostać polityką unijną, a państwa członkowskie w swoich działaniach zewnętrznych powinny wspierać jej cele. Był to wyraźny sygnał, skierowany do tych państw, które w poprzednich latach zaczęły podważać sens ogólnego podejścia UE do państw sąsiedzkich, kierując się swoimi interesami regionalnymi.

W obliczu zmian, które zaszły w państwach Afryki Północnej, UE zaproponowała nowe podejście w ramach EPS. Miało ono oznaczać, że Komisja będzie stosować dużo bardziej elastyczne instrumenty w odniesieniu do poszczególnych państw, które będą odpowiadać staraniom i możliwościom tych ostatnich. Na pierwszym miejscu UE niezmiennie dąży do zagwarantowania i wzmocnienia systemów demokratycznych - „głębokiej i trwałej demokracji” (Nowa, 2011, s. 4) w swoich państwach sąsiedz-

${ }^{6}$ Oryginalna propozycja Francji zakładała utworzenie Unii Śródziemnomorskiej, w której uczestniczyłyby państwa europejskie i partnerskie mające dostęp do Morza Śródziemnego, co wkluczałoby dużą liczbę państw UE z tego projektu. Został on skrytykowany, głównie przez Niemcy, i w efekcie Francja przedstawiła nowy projekt obejmujący wszystkie państwa UE i partnerów południowych. 
kich. Wprowadzono zasadę „więcej za więcej” (ang. more for more), która oznacza, że państwa, które wykażą się postępami w zakresie budowania i konsolidacji demokracji będą mogły liczyć na preferencje w handlu oraz inne korzyści, np. udział w kolejnych programach unijnych. Zaznaczono także, że UE nie będzie współpracować z państwami, które dopuszczają się łamania praw człowieka i zasad demokracji, ale jednocześnie podkreślono, że w takich przypadkach Unia zwiększy swoje wsparcie dla społeczeństw obywatelskich w tych państwach.

Kolejny element nowego podejścia to sprzyjanie rozwojowi służącemu włączeniu społecznemu, czyli wsparcie wymiany handlowej stymulującej wzrost gospodarczy, co ma przełożyć się na wzrost gospodarczy w państwach sąsiedzkich. Chodzi także o to, by pozytywne efekty wzrostu gospodarczego przyczyniały się do niwelowania różnic społecznych i eliminowania biedy. Instrumentem służącym wzmocnieniu więzi handlowych ma być stworzenie systemu pogłębionych i kompleksowych stref wolnego handlu, które mają opierać się na zbliżeniu i dostosowaniu do unijnych przepisów prawnych (sanitarnych, fitosanitarnych, w zakresie wolnej konkurencji, etc.) w państwach sąsiedzkich, co $\mathrm{w}$ efekcie da dostęp towarom z tych państw do rynku wewnętrznego UE. Także współpraca sektorowa została wskazana jako kolejny istotny element nowego podejścia. Unii zależy na współpracy z państwami sąsiedzkimi, ale także między samymi państwami EPS, w takich dziedzinach jak: energetyka, transport, zmiany klimatyczne czy wiedza i innowacyjność (Nowa, 2011, s. 10-12).

Komisja, biorąc pod uwagę zinstytucjonalizowanie się dwóch kierunków EPS - południowego i wschodniego, w kolejnym punkcie zwróciła uwagę na konieczność wypracowania wspólnych inicjatyw regionalnych, które nie będą konkurencyjne względem siebie, lecz będą mieć charakter komplementarny. Zaznaczono, że regionalizacja EPS wynika z uwarunkowań historycznych i specyfiki wcześniejszych doświadczeń współpracy. Ważnym elementem pojawiającym się w komunikacie jest „wzajemna rozliczalność", przy czym termin ten nie został dokładnie wyjaśniony, niemniej należy go łączyć z wywiązywaniem się stron ze zobowiązań. W ten sposób Unia zabezpiecza swoje interesy, tak by w zamian za koncesje handlowe czy wsparcie finansowe, móc egzekwować oczekiwania reform politycznych po stronie państw sąsiedzkich.

W latach 2006-2011, czyli w pierwszym okresie realizacji EPS, Komisja Europejska w wydawanych komunikatach uszczegóławiała agendę określoną w komunikacie z 2004 r. Dokumenty z 2006 i 2007 r. nie wprowadzały zasadniczo żadnych istotnych zmian w celach i zasadach EPS. Dopiero Komunikat z 2011 r. można uznać za pierwszą reformę tej polityki, głównie ze względu na zaakcentowanie zasady „więcej za więcej” i połączenie jej z ,wzajemną rozliczalnością”, a także uwzględnienie w założeniach EPS wyraźnego podziału na wymiar południowy i wschodni, który dokonał się w latach wcześniejszych.

\section{Nowa Europejska Polityka Sąsiedztwa}

Mimo pierwotnych optymistycznych reakcji UE na przemiany polityczno-społeczne w Afryce Północnej, wyrażonych m.in. w komunikacie z 2011 r. szybko okazało się, że stare dyktatury zostały zastąpione nowymi (Egipt), lub kraj pogrą̇zył się w cha- 
osie (Libia). Najgorzej sytuacja przedstawia się w Syrii, gdzie od 2011 r. nieprzerwanie trwa wojna domowa. Jedynie w przypadku Tunezji można mówić o sukcesie tamtejszej ,jaśminowej rewolucji”. Okazało się również, że nie tylko w południowym obszarze EPS występują problemy. Kryzys ukraiński zapoczątkowany politycznym impasem związanym z ratyfikowaniem umowy stowarzyszeniowej z UE, przerodził się w jeden z najpoważniejszych konfliktów w powojennej Europie. Aneksja Krymu dokonana przez Rosję i otwarty konflikt na wschodzie Ukrainy powodują, że Unia Europejska stanęła przed zupełnie nowym wyzwaniem. Problemy w południowym i wschodnim sąsiedztwie unaoczniły słabości dotychczas realizowanej przez UE polityki. Jeśli za strategiczny cel EPS uznać próbę zagwarantowania strefy pokoju i bezpieczeństwa na zewnętrznych granicach Unii, to w kontekście obu wymiarów EPS, polityka ta zakończyła się niepowodzeniem. Z drugiej strony oczywiście trudno dowieść, że działania czy zaniechania Unii przyczyniły się bezpośrednio do obu kryzysów. Niemniej nie można nie zadać pytania o skuteczność wcześniejszych założeń EPS i ich realizację. To właśnie pytanie, a także konieczność wypracowania nowych mechanizmów w zmienionej rzeczywistości międzynarodowej, stały się początkiem nowej reformy EPS. Rok 2015 w UE przebiegał w dużej mierze pod znakiem debaty o nowej polityce sąsiedztwa. W proces ten zaangażowane zostały niemal wszystkie najważniejsze instytucje, włączając w to Komisję Europejską, Parlament Europejski, Radę oraz Radę Europejską. Kalendarium najważniejszych dokumentów dotyczących reformy EPS, przyjętych w 2015 r. przedstawia się następująco:

1) 4 marca: Wspólny dokument konsultacyjny Komisji Europejskiej „W stronę nowej europejskiej polityki sąsiedztwa" (JOIN(2015)0006);

2) 19 i 20 marca: Konkluzje z Posiedzenia Rady Europejskiej;

3) 20 kwietnia: Konkluzje Rady w sprawie przeglądu europejskiej polityki sąsiedztwa;

4) 9 lipca: Rezolucja Parlamentu Europejskiego w sprawie przeglądu europejskiej polityki sąsiedztwa (P8_TA-PROV(2015)0272);

5) 18 listopada: Wspólny komunikat Komisji Europejskiej do Parlamentu Europejskiego, Rady, Europejskiego Komitetu Ekonomiczno-Społecznego i Komitetu Regionów „Przegląd Europejskiej Polityki Sąsiedztwa” (JOIN(2015) 50);

6) 14 grudnia: Konkluzje Rady w sprawie przeglądu europejskiej polityki sąsiedztwa. Pierwszy z dokumentów, przedstawiony przez Komisję Europejską, stanowił formalne rozpoczęcie procesu przeglądu EPS. Podkreślono, że: „W chwili obecnej nasze sąsiedztwo jest mniej stabilne niż dziesięć lat temu” i dalej „EPS nie zawsze była w stanie odpowiednio reagować ani na te ostatnie wydarzenia, ani na zmieniające się aspiracje naszych partnerów. W związku z tym interesy UE nie zostały w pełni zaspokojone" (W stronę, 2015, s. 2). W sekcji drugiej dokumentu opisano dotychczasowe dziesięcioletnie doświadczenia z realizacji EPS oraz postawiono szereg szczegółowych pytań dotyczących funkcjonalności tej polityki. Zwrócono uwagę na osiagnięcia EPS, w tym wzrost kontaktów handlowych z państwami sąsiedztwa oraz regulacje w zakresie przepływów migracyjnych. Jednak nie wszystkie pierwotne założenia polityki udało się zrealizować, co często wynikało z braku zainteresowania lub możliwości instytucjonalnych partnerów Unii. Sekcja trzecia poświęcona została obszarom wskazanym przez państwa członkowskie i partnerskie, jako te, które wymagają poprawy bądź nowego uregulowania. Podzielono je na cztery kategorie: zróżnicowanie; ukie- 
runkowanie; elastyczność; odpowiedzialność i widoczność. Pierwsza kategoria dotyczy pytania, czy w ramach EPS jest miejsce na „zmienną optykę”, która pozwalałaby na ustanawianie przez Unię różnych rodzajów stosunków w odniesieniu do poszczególnych państw sąsiedzkich, uzależnione od poziomu ich zaangażowania. Ukierunkowanie odniesiono do potrzeby sprecyzowania obszarów „najsilniejszego wspólnego zainteresowania”, które są zbieżne po stronie Unii i poszczególnych państw sąsiedztwa. Chodzi o wyłonienie kilku priorytetowych kwestii dla każdego państwa, aby w ten sposób skoncentrować środki na ich realizacji. Elastyczność można uznać za jedną z kluczowych kwestii postawionych przed reformą EPS. Zasadnicze pytanie dotyczy oceny postępów w zakresie realizacji planów działania w państwach sąsiedztwa. Szczególna uwaga poświęcona została państwom ogarniętym konfliktami, gdyż tego typu sytuacje kryzysowe nie pozwalają na stosowanie ogólnych instrumentów oceny. Ostatnia kategoria, czyli odpowiedzialność i widoczność, to punkt odnoszący się do konieczności zwiększenia świadomości społecznej i wiedzy w państwach partnerskich na temat działań podejmowanych w ramach EPS, tak by obywatele łączyli pozytywne przemiany w swoich państwach z działaniami Unii i w ten sposób wywierali oddolną presję na rządzących, aby kontynuować procesy reform i zacieśniania relacji z UE. Ten punkt to także pytanie o możliwość większego zaangażowania państw członkowskich UE w działania wspierające cele EPS.

Rada Europejska na posiedzeniu w dniach 19-20 marca 2015 r. uznała, że zapoczątkowany przez Komisję przegląd EPS powinien potwierdzić zaangażowanie Unii w relacje z państwami sąsiedzkimi zarówno południowymi, jak i wschodnimi.

Rada ds. Zagranicznych na posiedzeniu 20 kwietnia również odniosła się do dokumentu KE i z zadowoleniem przyjęła zapowiedź przeglądu EPS. Co do zasady, Rada zaakceptowała większość punktów zaproponowanych przez Komisję. Podkreślono konieczność uproszczenia procedur w ramach EPS, tak by w przyszłości polityka ta była bardziej elastyczna i aby można było szybciej i efektywniej reagować na zmiany zachodzące w państwach partnerskich przy zachowaniu ciagłości działania i jego przewidywalności (Konkluzje Rady, 20 kwietnia 2015, punkt 7).

Kolejną instytucją Unii, która podjęła temat reformy EPS, był Parlament Europejski (PE), który przyjął rezolucję w tej sprawie 9 lipca 2015 r. Jest to dokument stosunkowo obszerny, w którym zwrócono uwagę zarówno na ogólny charakter EPS, jak też zawarto szczegółowe uwagi i propozycje. Parlament, podobnie jak wcześniej inne instytucje, podkreślił, że reforma EPS powinna przede wszystkim pomóc Unii efektywniej reagować na zmiany zachodzące w sąsiedztwie, bowiem zarówno arabska wiosna, jak i kryzys ukraiński pokazały, że dotychczasowe mechanizmy się nie sprawdzają. Ciekawym punktem rezolucji jest stwierdzenie o konieczności powrotu $\mathrm{w}$ ramach EPS do pierwotnych celów, jakimi były stworzenie obszaru dobrobytu, stabilności, bezpieczeństwa i dobrego sąsiedztwa opartego na wspólnych wartościach i zasadach Unii (Rezolucja, 2015, s. 5). Z perspektywy relacji międzyinstytucjonalnych w Unii ważne są zawarte w Rezolucji postulaty PE. Najważniejsze, ale także najtrudniejsze do zrealizowania, to wezwanie skierowane bezpośrednio do Wysokiej Przedstawiciel do opracowania propozycji w zakresie relacji handlowych skierowanych do państw sąsiedzkich wzorowanych na rozwiązaniach obowiązujących w ramach Europejskiego Obszaru Gospodarczego. Kolejny istotny punkt Rezolucji to żądanie sformułowania 
przez Komisję krótko-, średnio- i długoterminowych priorytetów oraz celów strategicznych uwzględniających interesy państw sąsiedztwa oraz Unii (Rezolucja, 2015, s. 7). Parlament Europejski wyraził również troskę o zbyt niski, jego zdaniem, poziom finansowania EPS, zwłaszcza biorąc pod uwagę poziom zaangażowania podmiotów trzecich w państwach sąsiedzkich. Podkreślono, że zadaniem Komisji podczas opracowywania nowej EPS powinno być skorelowanie działań Unii i innych darczyńców i międzynarodowych instytucji finansowych wspomagających państwa sąsiedztwa. PE zaznaczył, że EPS nie może być programowana i realizowana w oderwaniu od innych działań zewnętrznych Unii, przede wszystkim podkreślono konieczność większej koordynacji między EPS a Wspólną Polityką Zagraniczną i Bezpieczeństwa oraz Wspólną Polityką Bezpieczeństwa i Obrony UE. To oznacza, że EPS jest traktowana jako ważny komponent strategii bezpieczeństwa Unii i w tym kontekście należy rozpatrywać jej założenia i cele. Temu też poświęcona jest duża część Rezolucji Parlamentu, gdzie kwestie bezpieczeństwa militarnego i pozamilitarnego w państwach sąsiedztwa są omawiane z punktu widzenia interesów strategicznych UE. Parlament zasygnalizował też potrzebę uregulowania stosunków Unii nie tylko z sąsiadami, ale również z „sąsiadami sąsiadów”, co pokazuje perspektywiczne myślenie o bezpieczeństwie w całym regionie EPS (Rezolucja, 2015, s. 13-14).

W kolejnych miesiącach propozycje Komisji Europejskiej były omawiane i konsultowane z państwami członkowskimi i partnerskimi, zainteresowanymi instytucjami UE i organizacjami pozarządowymi, łącznie do KE wpłynęło 250 odpowiedzi w ramach konsultacji publicznych (Przeglad, 2015, s. 2). W ich efekcie Komisja przygotowała kompleksowy dokument dotyczący reformy EPS zatytułowany „Przegląd Europejskiej Polityki Sąsiedztwa" przedstawiony 18 listopada 2015 r. We wstępie podkreślono, że: „Charakterystycznymi cechami nowej EPS będą większe zróżnicowanie i większa współwłasność, uznanie, że nie wszyscy partnerzy aspirują do przepisów i norm UE, oraz uwzględnienie potrzeb każdego kraju co do charakteru i ukierunkowania jego partnerstwa z UE" (Przeglad, 2015, s. 2). Pierwsza część dokumentu poświęcona została aktualnym wydarzeniom związanym z kryzysami w południowym i wschodnim sąsiedztwie i koniecznością ustabilizowania sytuacji politycznej w państwach objętych konfliktami. Zapowiedziano, że nowa EPS będzie skuteczniej przeciwdziałać tego typu sytuacjom wykorzystując m.in. mechanizmy wczesnego ostrzegania oraz dyplomację prewencyjną. Nowa EPS ma być również bardziej zindywidualizowana zarówno w aspekcie priorytetów, które będą odzwierciedlać aspiracje i możliwości poszczególnych państw, jak też przy ocenie, której podlegać będą cele uzgodnione wspólnie przez Unię i dane państwo. W ten sposób Komisja zamierza odejść od przedstawiania ogólnych sprawozdań z realizacji EPS. Jednocześnie potwierdzono wspólne cele polityki, czyli wspieranie uniwersalnych wartości - demokracji, dobrego zarządzania, rządów prawa, praw człowieka i podstawowych wolności, działania na rzecz stabilności w krajach partnerskich. Określono też zasady: zróżnicowanie i większą współodpowiedzialność krajów partnerskich, uwzględniające bardziej zindywidualizowane potrzeby każdego kraju i zakres jego partnerstwa z UE oraz zwiększone zaangażowanie Rady i państw członkowskich w EPS.

Komisja wytyczyła trzy obszary współpracy, na których ma koncentrować się nowa EPS. Po pierwsze, jest to rozwój gospodarczy, w ramach którego szczególne znaczenie 
mają mieć: walka z bezrobociem, współpraca w dziedzinie energetyki, wsparcie dla sektora MŚP. Po drugie, sektor bezpieczeństwa, zarówno w aspekcie militarnym, jak i pozamilitarnym, w tym zwalczanie terroryzmu i zapobieganie radykalizacji oraz walka ze zorganizowaną przestępczością. Po trzecie, kwestie migracji i mobilności, w tym bezpieczna i legalna migracja oraz wsparcie dla państw przyjmujących uchodźców.

Określono również nowe metody pracy. Najważniejsza ma być elastyczność dostępnych instrumentów i zasobów. Warto przypomnieć, że w aktualnie realizowanej perspektywie finansowej na lata 2014-2020 na realizację EPS przewidziano 15,4 mld euro. Odpowiadając na postulat Parlamentu Europejskiego Komisja zaznaczyła, że należy dążyć do większej koordynacji środków finansowych pochodzących z różnych źródeł, w tym od darczyńców zewnętrznych, ale „wspólne reakcje ze strony UE w danym regionie powinny być kształtowane wokół „marki unijnej” (Przeglad, 2015, s. 23). Jako warunek skutecznej realizacji EPS podkreślono konieczność eksponowania, komunikacji i kontaktów zewnętrznych służących lepszej promocji EPS wśród państw sąsiedztwa, ale także na arenie międzynarodowej, tłumacząc to w następujący sposób: „Lepsza dyplomacja publiczna przyczyni się do sprawniejszego uzasadniania logiki polityki UE i pozytywnego wpływu konkretnych działań UE” (Przeglad, 2015, s. 24).

Rada ds. Zagranicznych w konkluzjach z posiedzenia w dniu 14 grudnia 2015 r. w pełni zaakceptowała propozycje przedstawione przez Komisję. W ten sposób przegląd EPS zainicjowany wiosną 2015 r. zakończył się i rozpoczęła się faza realizacji oparta o nowo określone priorytety i zasady.

\section{Ocena reformy Europejskiej Polityki Sąsiedztwa. Podsumowanie}

Unia Europejska tworząc i rozwijając EPS postawiła przed sobą bardzo trudne zadanie. W odróżnieniu od tradycyjnych polityk europejskich, EPS charakteryzuje się dużą nieprzewidywalnością, a ilość faktorów niezależnych od UE jest zdecydowanie większa niż w przypadku jakiejkolwiek innej polityki.

Prace koncepcyjne nad reformą EPS odbywały się w czasie, gdy w wielu państwach członkowskich UE zaczęło kwestionować sens bliższych relacji z państwami sąsiedztwa, podkreślając, że wydarzenia arabskiej wiosny pokazały nie tylko słabość działań UE, ale wręcz udowodniły, że prawdziwe zaangażowanie w tym regionie jest niemożliwe z uwagi na nieprzewidywalność partnerów. Problemem w relacjach z państwami sąsiedzkimi jest często ich roszczeniowa postawa, manifestująca się w oczekiwaniach finansowego wsparcia przy jednoczesnym markowaniu reform politycznych (Grevi, 2014, s. 17). Przedstawiona w listopadzie 2016 r. reforma EPS nie jest rewolucją lecz jest zapowiedzią i zobowiązaniem przede wszystkim KE i ESDZ, ale także Rady i PE do podjęcia w przyszłości działań mających na celu stworzenie bezpiecznego otoczenia dla Unii w ścisłej kooperacji z państwami sąsiedzkimi.

Przedstawiając założenia zreformowanej EPS politycy europejscy niemal jednogłośnie podkreślili jej związek z bezpieczeństwem UE. Johannes Hahn, komisarz ds. Europejskiej Polityki Sąsiedztwa i negocjacji akcesyjnych, powiedział: „Najważniejszym zadaniem w tej chwili jest zapewnienie stabilizacji w naszym sąsiedztwie. 
Konflikty, terroryzm i radykalizacja postaw stanowią zagrożenie dla nas wszystkich. Brak bezpieczeństwa jest też jednak skutkiem ubóstwa, korupcji i złego sprawowania rządów. Dlatego tam, gdzie istnieje taka potrzeba, skoncentrujemy się w kontaktach z partnerami na łączących nas wspólnych interesach. Kluczowym punktem w tym zakresie będzie rozwój gospodarczy, ze zwróceniem szczególnej uwagi na zatrudnienie i umiejętności młodzieży" (Przeglad..., Komunikat prasowy, 2015, s. 1). Także Wysoka Przedstawiciel Federica Mogherini w swojej wypowiedzi skoncentrowała się na tym samym aspekcie reformy: „Silniejsze partnerstwo z krajami sąsiednimi ma kluczowe znaczenie dla Unii Europejskiej, w czasie gdy borykamy się z wieloma wyzwaniami wewnątrz naszych granic, a także poza nimi. [...] Musimy wspólnie budować bezpieczniejsze otoczenie, starać się rozwiązywać liczne kryzysy obecne w naszym regionie, wspierać rozwój i wzrost w najbiedniejszych obszarach i przeciwdziałać przyczynom migracji” (Przeglad..., Komunikat praso$w y, 2015$, s. 1).

Reforma EPS z pewnością nie odpowiada na wszystkie wyzwania, które pojawiły się w ostatnich latach w kontekście relacji Unii z jej partnerami. Największe zastrzeżenia budzi brak uregulowań w zakresie kontroli przepływów finansowych. Także sam mechanizm transferowania środków bezpośrednio do budżetów państw sąsiedzkich jest krytykowany, ponieważ rodzi niebezpieczeństwo ich sprzeniewierzenia lub niewłaściwego wykorzystania (Kaca, 2016, s. 2). W tej sytuacji lepszym rozwiązaniem byłby system projektów i grantów, co dawałoby szansę na lepsze wykorzystanie przydzielonego wsparcia i jednocześnie otwierało drogę do starania się o środki przez podmioty pozarządowe. Niemniej należy pamiętać, że Unia Europejska przedstawiła reformę EPS będącą w dużej mierze odpowiedzią na aktualne wydarzenia na arenie sąsiedztwa. W tym kontekście nie należało oczekiwać pogłębionej analizy i zasadniczych zmian.

Reasumując i odpowiadając na pytania badawcze sformułowane we wstępie, należy podkreślić, że Europejska Polityka Sąsiedztwa stanowi ważny element europejskiej strategii bezpieczeństwa oraz budowania pozycji międzynarodowej przez UE. W tym kontekście pierwotne założenia EPS sformułowane w 2004 r. nadal zachowały swoją aktualność. Z punktu widzenia prawa międzynarodowego publicznego wszystkie państwa są suwerenne i równe, co nie oznacza bynajmniej wchodzenia przez nie w różnego rodzaju relacje i tworzenie wzajemnych zależności. EPS jest tego wyraźnym przykładem. Za pomocą bodźców finansowych Unia stara się wpływać na procesy demokratyzacyjne w państwach sąsiedzkich. Reforma opracowana w 2015 r. jest pierwszym krokiem w kierunku stworzenia nowej Europejskiej Polityki Sąsiedztwa, której nie można postrzegać w kategoriach statycznych, lecz należy ją traktować jako dynamiczny proces, gdzie Unia reaguje na wydarzenia zachodzące w państwach sąsiedzkich. Można oczywiście w tym miejscu postawić pytanie, czy Unia nie powinna zmienić optyki i z pozycji podmiotu pasywnego, nie przejść do bardziej aktywnych działań. Jednak wydaje się, że taka postawa mogłaby zostać odebrana negatywnie przez państwa sąsiedzkie, jako zbyt ofensywna i godząca w ich prawa suwerenne. Dlatego w kolejnych latach należy oczekiwać kontynuacji EPS, której zasadniczym i stałym celem jest przede wszystkim zwiększenie poziomu bezpieczeństwa wewnętrznego i zewnętrznego Unii. 


\section{Bibliografia}

Borkowski P. J. (2005), Partnerstwo Eurośródziemnomorskie, Oficyna Wydawnicza ASPRA_JR, Warszawa.

Böttger K. (2010), Die Entstehung und Entwicklung der Europäischen Nachbarschaftspolitik. Akteure und Koalitionen, Europäische Schriften Bd. 87, Nomos Verlag, Baden-Baden.

Council Conclusions, $18^{\text {th }}$ November 2002 r., http://www.consilium.europa.eu/ueDocs/cms_Data/ docs/pressData/en/gena/73248.pdf.

Dokumenty informacyjne o Unii Europejskiej - Europejska Polityka Sasiedztwa (2016), http://www. europarl.europa.eu/ftu/pdf/pl/FTU_6.5.4.pdf.

Europejska Polityka Sasiedztwa - Strategia - Komunikat Komisji, Bruksela 12 maja 2004 r., COM (2004) 373 final.

Fiszer J. M. (red.) (2012), Europejska polityka sqsiedztwa Unii Europejskiej: geneza, doświadczenia, perspektywy, Dom Wydawniczy Elipsa, Warszawa.

Ghazaryan N. (2014), European Neighbourhood Policy and the Democratic Values of the EU, Hart Publishing, Oxford-Portland, Oregon.

Grevi G. (2014), Re-defining the EU's neighbourhood, w: Challenges for European Foreign Policy in 2014 The EU's extended neighbourhood, red. G. Grevi, D. Keohane, Fride, Madrid.

Haukkala H. (2008), The European Union as a Regional Normative Hegemon: The Case of European Neighbourhood Policy, „Europe - Asia Studies”, vol. 60, issue 9.

Jartyś J., Staszczyk A. (red.) (2008), Polityka Sasiedztwa Unii Europejskiej. Pomostowość czy buforowość?, Zapol, Szczecin.

Kaca E. (2015), Przeglad polityki sqsiedztwa: niewystarczajace zmiany, „Biuletyn PISM”, nr 106 (1343).

Kalicka-Mikołajczyk A. (2013), Ramy prawne i zasady unijnej Europejskiej Polityki Sasiedztwa wobec partnerów wschodnich, Wydawca Prawnicza i Ekonomiczna Biblioteka Cyfrowa, Warszawa.

Konkluzje Rady w sprawie przegladu europejskiej polityki sqsiedztwa z dnia 20 kwietnia 2015 r., http://www.consilium.europa.eu/pl/press/press-releases/2015/04/20-council-conclusions-review-european-neighbourhood-policy/.

Konkluzje Rady w sprawie przeglqdu europejskiej polityki sqsiedztwa z dnia 14 grudnia 2015 r., $15169 / 15$.

Konkluzje Rady w sprawie wzmacniania europejskiej polityki sqsiedztwa z dnia 19 czerwca 2007 r., 11016/07.

Konkluzje z Posiedzenia Rady Europejskiej w dniach 19 i 20 marca 2015 r., EUCO 11/15.

Marcinkowska P. (2011), Europejska Polityka Sasiedztwa. Unia Europejska i jej sqsiedzi-wzajemne relacje $i$ wyzwania, Wyd. Uniwersytetu Warszawskiego, Warszawa.

Normann Ch. (2014), The Influence of EU Member States on European Neighbourhood Policy. A Comparative Analysis of Germany, France and Poland, Nomos Verlag, Baden-Baden.

Nowa koncepcja działań w obliczu zmian zachodzacych w sasiedztwie. Komunikat Komisji Europejskiej, $\operatorname{KOM}(2011) 303$ wersja ostateczna.

Pracujmy wspólnie. Europejska Polityka Sasiedztwa (2006), Urząd Oficjalnych Publikacji Wspólnot Europejskich, Luksemburg.

Przeglad europejskiej polityki sqsiedztwa (EPS): zacieśnione partnerstwo na rzecz silniejszego sqsiedztwa, Komisja Europejska - Komunikat prasowy, Bruksela, 18 listopada 2015, http:// europa.eu/rapid/press-release_IP-15-6121_pl.htm.

Przeglad Europejskiej Polityki Sasiedztwa. Wspólny komunikat Komisji Europejskiej do Parlamentu Europejskiego, Rady, Europejskiego Komitetu Ekonomiczno-Społecznego i Komitetu Regionów, JOIN(2015) 50. 
Rezolucja Parlamentu Europejskiego w sprawie przegladu europejskiej polityki sqsiedztwa z 9 lipca 2015 r., P8_TA-PROV(2015)0272.

Rozporzadzenie (WE) nr 1638/2006 Parlamentu Europejskiego i Rady UE z dnia 24 października 2006 r., Dz. U. UE L 310, z dnia 9.11.2006.

Silna europejska polityka sqsiedztwa. Komunikat Komisji Europejskiej przyjęty 5 grudnia 2007 r., $\mathrm{KOM}(2007) 774$ wersja ostateczna.

Solana J., Patten Ch. (2002), Wider Europe, http://www.lfpr.lt/uploads/File/2002-10/Letter.pdf, 5.05.2012.

Szersza Europa - Sqasiedztwo: Nowe ramy stosunków z naszymi wschodnimi i poludniowymi sq́siada$m i$, Bruksela 11 marca 2003 r., COM (2003) 104 final.

Varwick J., Lang K. O. (red.) (2007), European Neighbourhood Policy: Challenges for the EU-Policy Towards the New Neighbours, Barbara Budrich Publishers, Opladen.

W sprawie wzmocnienia Europejskiej Polityki Sasiedztwa. Komunikat Komisji Europejskiej z 6 grudnia 2006 r., COM (2006) 726 final.

$W$ stronę nowej europejskiej polityki sqsiedztwa, Wspólny dokument konsultacyjny, JOIN(2015)0006.

Zięba R. (2007), Wspólna Polityka Zagraniczna i Bezpieczeństwa Unii Europejskiej, Wydawnictwa Akademickie i Profesjonalne, Warszawa.

\section{Streszczenie}

Po przeszło 12 latach realizacji EPS i dwóch wstrząsach politycznych - kryzysie ukraińskim i arabskiej wiośnie, nadszedł czas kompleksowej oceny i rewizji niektórych założeń. W 2015 r. rozpoczęły się konsultacje dotyczące nowego kształtu EPS, tak by polityka ta z jednej strony nadal wypełniała swoją zasadniczą funkcję wspierania i promocji praw człowieka i demokracji w państwach sąsiedzkich, ale z drugiej strony by UE mogła efektywniej wpływać na swoje bezpieczeństwo zewnętrzne. Po ponad półrocznym okresie konsultacji, w których udział wzięły zarówno instytucje UE, państwa członkowskie, a także organizacje pozarządowe, w listopadzie 2015 roku Komisja Europejska przedstawiła założenia reformy EPS, które można określić jako nową Europejską Politykę Sąsiedztwa. W artykule przedstawiony został dotychczasowy model EPS, w tym także przesłanki ustanowienia polityki w 2004 r., następnie ukazana została ewolucja EPS, a w kolejnej części artykułu omówione zostały założenia nowej EPS na podstawie analizy dokumentów instytucji UE.

Slowa kluczowe: Europejska Polityka Sąsiedztwa, Unia Europejska, relacje zewnętrzne UE

\section{Towards a new European Neigbourhood Policy of the European Union}

\section{Summary}

After over 12 years of implementation of the European Neighbourhood Policy and the two political upheavals - Ukrainian crisis and the Arab Spring, it is time for its comprehensive assessment and review of certain assumptions. In 2015 began consultations on a new shape of the ENP, so that the policy on the one hand might continue to fulfill its essential function of supporting and promoting human rights and democracy in neighboring countries, but on the other hand, the EU can effectively influence their external security. After more than six months of consultations, which was attended by the EU institutions, Member States and non-governmental organi- 
zations, in November 2015, the European Commission presented the principles of the reform of the ENP, which can be described as the new European Neighbourhood Policy. The paper presents the current model of the ENP, including evidence to establish policy in 2004., then is shown the evolution of the policy and in the next part of the article is discussed the establishment of a new ENP based on analysis of documents of the EU institutions.

Key words: European Neighbourhood Policy, European Union, EU’ external relations 